\title{
Minat Belajar Mahasiswa terhadap Pembelajaran Chookai
}

\author{
Anisa Arianingsih, Soni Mulyawan Setiana \\ Program Studi Sastra Jepang \\ Universitas Komputer Indonesia \\ anisa@email.unikom.ac.id
}

\begin{abstract}
ABSTRAK
Penelitian ini bertujuan untuk mengetahui seberapa besar minat belajar mahasiswa dalam mengikuti perkuliahan Chookai IV di Program Studi Sastra Jepang Unikom. Metode yang digunakan adalah analisis deskriptif. Pengumpulan data dilakukan dengan cara menyebarkan kuesioner dan studi pustaka. Sampel dalam penelitian ini adalah mahasiswa semester IV tahun akademik 2017/2018. Hasil penelitian menunjukkan bahwa minat belajar mahasiswa dalam mengikuti perkuliahan Chookai IV adalah tinggi dilihat dari segi ketertarikan sebesar 96,9\%, rasa senang sebesar $84,4 \%$, dan semangat untuk mengikuti perkuliahan Chookai IV sebesar $75 \%$. Selain itu minat mahasiswa untuk mengerjakan tugas dengan baik dan tepat waktu pun tinggi. Akan tetapi, minat mahasiswa untuk selalu hadir dalam perkuliahan dan minat untuk mengulang kembali materi yang telah dipelajari masih belum baik. Untuk itu dosen perlu melakukan evaluasi lebih mendalam terkait dengan metode penugasan sebelum dan sesudah pembelajaran guna perbaikan hasil belajar mahasiswa.
\end{abstract}

Kata kunci: minat belajar, mahasiswa, pembelajaran, Chookai

\section{ABSTRACT}

This research aims to discover the extent of students' learning interest in studying Chookai IV in Japanese Department Unikom. The method used is descriptive analysis. Data collection was done by distributing questionnaires and literature study. The samples in this research were students of semester IV in the academic year of 2017/2018. The results showed that the student's interest in following Chookai IV lecture was 
high in terms of interest with $96.9 \%$, the pleasure with $84.4 \%$, and the enthusiasm to follow the lecture of Chookai IV by $75 \%$. In addition, the students' interest to do the job well and on time was high. However, the interest of students to always be present in the lectures and interest to repeat the material that has been studied is still not good. Therefore, lecturers need to conduct a deeper evaluation related to the method of assignment before and after the learning in order to improve students' learning outcomes.

Keywords: learning interest, student, learning, Chookai

\section{Pendahuluan}

Keterampilan menyimak sebagai salah satu unsur dari empat keterampilan berbahasa memiliki peranan penting dalam penguasaan bahasa yang berfungsi menerima informasi secara lisan. Tarigan (1986) mengemukakan bahwa menyimak adalah suatu proses kegiatan mendengarkan lambang-lambang lisan dengan penuh perhatian, pemahaman, apresiasi, serta interpretasi untuk memperoleh informasi, menangkap isi atau pesan serta memahami makna komunikasi yang telah disampaikan oleh pembicara melalui ujaran atau bahasa lisan.

Sudjianto (2012) menjelaskan bahwa terdapat beberapa keterampilan yang harus dimiliki dalam kegiatan menyimak, antara lain: 1) kemampuan mengidentifikasi bunyi suara; 2) kemampuan mengidentifikasi komponen-komponen kebahasaan seperti kata, dan sebagainya; 3) kemampuan untuk memahami makna dengan cara menghubungkan bunyi yang didengar dengan kata-kata yang sudah diketahui; 4) kemampuan untuk memahami arti secara gramatikal; 5) kemampuan menangkap intisari; dan 6) kemampuan membuat catatan-catatan sambil mendengar.

Selanjutnya, Setyandari (2015) mengemukakan tentang pentingnya menyimak yaitu bahwa keterampilan menyimak memberikan kontribusi yang sangat besar untuk meningkatkan kemampuan keterampilan berbahasa yang lainnya, terutama keterampilan berbicara dan menulis. Oleh karena itu, pembelajaran menyimak dilaksanakan secara terpadu dan memerlukan perhatian khusus. 
Salah satu faktor keberhasilan dalam mencapai tujuan pembelajaran menyimak atau dalam bahasa Jepang disebut Chookai adalah adanya minat mahasiswa dalam belajar Chookai itu sendiri. Aritonang (2008) menjelaskan bahwa minat dan motivasi belajar merupakan hal yang penting dalam menentukan hasil belajar. Oleh karena itu, penting bagi pengajar untuk dapat memberikan minat dan motivasi belajar kepada siswanya.

Seseorang dikatakan memiliki minat terhadap sesuatu jika ia mempunyai perasaan senang, tertarik, dan penuh perhatian atau bersemangat terhadap sesuatu hal tersebut. Djamarah (2002) menjelaskan bahwa ada beberapa yang menjadi indikator minat belajar yaitu rasa suka atau senang, pernyataan lebih menyukai, adanya rasa ketertarikan adanya kesadaran untuk belajar tanpa disuruh, berpartisipasi dalam aktivitas belajar, dan memberikan perhatian. Selanjutnya menurut Slameto (2010), indikator minat belajar meliputi perasaan senang, ketertarikan, penerimaan, dan keterlibatan siswa.

Penelitian ini akan memaparkan seberapa besar minat belajar mahasiswa yang mencakup ketertarikan, perasaan senang, semangat, tingkat kehadiran, ketepatan waktu dan keseriusan dalam mengerjakan tugas, serta minat mahasiswa dalam mempelajari materi sebelum ataupun sesudah mengikuti perkuliahan Chookai IV pada Program Studi Sastra Jepang Fakultas Sastra Universitas Komputer Indonesia.

\section{Metode Penelitian}

Penelitian ini adalah menggunakan metode deskriptif dengan sampel sebanyak 32 orang yang mengambil mata kuliah Chookai IV tahun akademik 2017/2018. Pengambilan data digunakan dengan cara menyebarkan kuesioner menggunakan google form dan studi pustaka. Kuesioner yang telah terkumpul kemudian dihitung frekuensi dan persentasenya. Setelah itu ditafsirkan mengikuti pedoman sebagai berikut. 
Tabel 1. Penafsiran Persentase Kuesioner

\begin{tabular}{|c|c|c|}
\hline No. & Persentase & Penafsiran \\
\hline 1 & $100 \%$ & Seluruhnya \\
\hline 2 & $90 \%-99 \%$ & Hampir seluruhnya \\
\hline 3 & $60 \%-89 \%$ & Sebagian besar \\
\hline 4 & $51 \%-59 \%$ & Lebih dari setengahnya \\
\hline 5 & $50 \%$ & Setengahnya \\
\hline 6 & $40 \%-49 \%$ & Hampir setengahnya \\
\hline 7 & $10 \%-39 \%$ & Sebagian kecil \\
\hline 8 & $1 \%-9 \%$ & Sedikit sekali \\
\hline 9 & $0 \%$ & Tidak ada sama sekali \\
\hline
\end{tabular}

(Sudjiono, 2003)

\section{Hasil dan Pembahasan}

Pengumpulan data kuesioner dilakukan dengan menggunakan google form dan disebarkan kepada 32 mahasiswa semester IV pada bulan Juli 2018. Data yang diperoleh kemudian diolah dengan menggunakan SPSS. Adapun hasilnya adalah sebagai berikut.

Ketertarikan mahasiswa dalam mengikuti perkuliahan Chookai IV disajikan dalam tabel 2 di bawah ini.

Tabel 2 Ketertarikan mahasiswa dalam mengikuti perkuliahan

\begin{tabular}{|r|r|r|r|r|}
\hline & & & & Chookai IV \\
& Frequency & Percent & Valid Percent & Percent \\
\hline Valid & 1 & 3.1 & 3.1 & 3.1 \\
\hline & 20 & 62.5 & 62.5 & 65.6 \\
\hline & 11 & 34.4 & 34.4 & 100.0 \\
\hline & 32 & 100.0 & 100.0 & \\
\hline
\end{tabular}

Dari tabel 2 di atas terlihat bahwa sedikit sekali $(3,1 \%)$ mahasiswa tidak tertarik dalam mengikuti perkuliahan Chookai IV, sebagian besar $(62,5 \%)$ mahasiswa tertarik mengikuti perkuliahan Chookai IV, dan sebagian kecil (34,4\%) mahasiswa sangat tertarik mengikuti perkuliahan Chookai IV. Selanjutnya, rasa senang mahasiswa dalam mengikuti perkuliahan Chookai IV disajikan dalam tabel 3 di bawah ini. 
Tabel 3 Rasa Senang terhadap mata kuliah Chookai IV

\begin{tabular}{|l|r|r|r|r|}
\hline & & & & Cumulative \\
& Frequency & Percent & Valid Percent & Percent \\
\hline Valid & 5 & 15.6 & 15.6 & 15.6 \\
\hline & 19 & 59.4 & 59.4 & 75.0 \\
\hline & 8 & 25.0 & 25.0 & 100.0 \\
\hline & 32 & 100.0 & 100.0 & \\
\hline
\end{tabular}

Dari tabel 3 di atas terlihat bahwa sebagian kecil $(15,6 \%)$ mahasiswa tidak senang dalam mengikuti perkuliahan Chookai IV, lebih dari setengahnya $(59,4 \%)$ mahasiswa senang mengikuti perkuliahan Chookai IV, dan sebagian kecil (25\%) mahasiswa sangat senang mengikuti perkuliahan Chookai IV. Adapun semangat mahasiswa dalam mengikuti perkuliahan Chookai IV disajikan dalam tabel 4.

Tabel 4 Semangat mahasiswa dalam mengikuti perkuliahan Chookai IV

\begin{tabular}{|l|r|r|r|c|}
\hline & & & & Cumulative \\
& Frequency & Percent & Valid Percent & Percent \\
\hline Valid & 8 & 25.0 & 25.0 & 25.0 \\
\hline & 17 & 53.1 & 53.1 & 78.1 \\
\hline & 7 & 21.9 & 21.9 & 100.0 \\
\hline & 32 & 100.0 & 100.0 & \\
\hline
\end{tabular}

Dari tabel 4 di atas terlihat bahwa sebagian kecil (25\%) mahasiswa tidak bersemangat dalam mengikuti perkuliahan Chookai IV, lebih dari setengahnya $(53,1 \%)$ mahasiswa bersemangat mengikuti perkuliahan Chookai IV, dan sebagian kecil (21,9\%) mahasiswa sangat bersemangat mengikuti perkuliahan Chookai IV. Selanjutnya, tingkat kehadiran mahasiswa dalam mengikuti perkuliahan Chookai IV disajikan dalam tabel 5. 
Tabel 5 Tingkat kehadiran dalam mata kuliah Chookai IV

\begin{tabular}{|r|r|r|r|r|}
\hline & & & & Cumulative \\
& Frequencv & Percent & Valid Percent & Percent \\
\hline Valid & 1 & 3.1 & 3.1 & 3.1 \\
\hline & 13 & 40.6 & 40.6 & 43.8 \\
& 9 & 28.1 & 28.1 & 71.9 \\
& 9 & 28.1 & 28.1 & 100.0 \\
\hline & 32 & 100.0 & 100.0 & \\
\hline
\end{tabular}

Dari tabel 5 di atas terlihat bahwa sebagian kecil $(3,1 \%)$ mahasiswa sangat tidak setuju dengan pernyataan bahwa dia tidak pernah bolos dalam perkuliahan Chookai IV, hampir setengahnya (40,6\%) mahasiswa tidak setuju dengan pernyataan bahwa dia tidak pernah bolos dalam perkuliahan Chookai IV, sebagian kecil $(28,1 \%)$ mahasiswa setuju dengan pernyataan bahwa dia tidak pernah bolos dalam perkuliahan Chookai IV, dan sebagian kecil $(28,1 \%)$ mahasiswa sangat setuju dengan pernyataan bahwa dia tidak pernah bolos dalam perkuliahan Chookai IV. Lebih lanjut, keseriusan mahasiswa dalam mengikuti perkuliahan Chookai IV disajikan dalam tabel 6.

Tabel 6 Keseriusan dalam pengerjaan tugas mata kuliah Chookai IV

\begin{tabular}{|r|r|r|r|r|}
\hline & Frequencv & Percent & Valid Percent & Cumulative Percent \\
\hline Valid 2 & 4 & 12.5 & 12.5 & 12.5 \\
4 & 19 & 59.4 & 59.4 & 71.9 \\
5 & 9 & 28.1 & 28.1 & 100.0 \\
\hline Total & 32 & 100.0 & 100.0 & \\
\hline
\end{tabular}

Dari tabel 6 di atas terlihat bahwa sebagian kecil (12,5\%) mahasiswa tidak mengerjakan tugas mata kuliah Chookai IV dengan baik, lebih dari setengahnya $(59,4 \%)$ mahasiswa mengerjakan tugas mata kuliah Chookai IV dengan baik, dan sebagian kecil $(28,1 \%)$ mahasiswa mengerjakan tugas mata kuliah Chookai IV dengan sangat baik. 
Adapun, ketepatan waktu mahasiswa dalam mengikuti perkuliahan Chookai IV disajikan dalam tabel 7 di bawah ini.

Tabel 7 Ketepatan waktu pengeriaan tugas mata kuliah Chookai IV

\begin{tabular}{|r|r|r|r|r|}
\hline & & & & $\begin{array}{c}\text { Cumulative } \\
\text { Percent }\end{array}$ \\
\hline Valid & Frequency & Percent & Valid Percent & 18.8 \\
\hline 2 & 6 & 18.8 & 18.8 & 62.5 \\
\hline & 14 & 43.8 & 43.8 & 100.0 \\
\hline & 12 & 37.5 & 37.5 & \\
\hline
\end{tabular}

Dari tabel 7 di atas terlihat bahwa sebagian kecil $(18,8 \%)$ mahasiswa tidak mengerjakan tugas mata kuliah Chookai IV tepat waktu, hampir setengahnya $(43,8 \%)$ mahasiswa mengerjakan tugas mata kuliah Chookai IV tepat waktu, dan sebagian kecil (37,5\%) mahasiswa selalu mengerjakan tugas mata kuliah Chookai IV tepat waktu.

Selanjutnya, kegiatan yoshuu yang dilakukan oleh mahasiswa sebelum mengikuti perkuliahan Chookai IV disajikan dalam tabel 8 di bawah ini. Tabel 8 Kegiatan yoshuu dalam mata kuliah Chookai IV

\begin{tabular}{|l|r|r|r|c|}
\hline & & & & Cumulative \\
& Frequencv & Percent & Valid Percent & Percent \\
\hline Valid & 17 & 53.1 & 53.1 & 53.1 \\
\hline 4 & 11 & 34.4 & 34.4 & 87.5 \\
5 & 4 & 12.5 & 12.5 & 100.0 \\
\hline Total & 32 & 100.0 & 100.0 & \\
\hline
\end{tabular}

Dari tabel 8 di atas terlihat bahwa lebih dari setengahnya $(53,1 \%)$ mahasiswa tidak mempersiapkan terlebih dahulu materi yang akan dipelajari di kelas, sebagian kecil $(34,4 \%)$ mahasiswa mempersiapkan terlebih dahulu materi yang akan dipelajari di kelas, dan sebagian kecil $(12,5 \%)$ mahasiswa selalu mempersiapkan terlebih dahulu materi yang akan dipelajari di kelas. Terkait dengan kegiatan fukushuu yang dilakukan oleh mahasiswa, disajikan dalam tabel 9 di bawah ini. 
Tabel 9 Kegiatan fukushuu dalam mata kuliah Chookai IV

\begin{tabular}{|r|r|r|r|r|}
\hline & Frequency & Percent & Valid Percent & Cumulative \\
Percent
\end{tabular}

Dari tabel 9 di atas terlihat bahwa lebih dari setengahnya (56,2\%) mahasiswa tidak mempelajari kembali materi yang telah diajarkan di rumah dan hampir setengahnya $(43,7 \%)$ mahasiswa mempelajari kembali materi yang telah diajarkan di rumah.

\section{Simpulan}

Minat belajar mahasiswa dalam mengikuti perkuliahan Chookai sangat tinggi, ini ditunjukkan dengan hasil penelitian yang menunjukkan bahwa ketertarikan, rasa senang, dan semangat mahasiswa dalam mengikuti mata kuliah Chookai yang tinggi. Selain itu minat mahasiswa untuk mengerjakan tugas dengan baik dan tepat waktu pun tinggi. Akan tetapi, minat mahasiswa untuk selalu hadir dalam perkuliahan dan minat untuk mengulang kembali materi yang telah dipelajari masih belum baik. Hal ini dapat dijadikan masukan bagi dosen pengampu agar hasil pembelajaran Chookai lebih maksimal.

\section{Referensi}

Aritonang, K.T. 2008. Minat dan Motivasi dalam Meningkatkan Hasil Belajar Siswa. Jakarta: Jurnal Pendidikan Penabur No. 10, hal 11-21. Tersedia dalam: http://bpkpenabur.or.id/wp-content/ uploads/2015/10/jurnal-No10-Thn7-Juni2008.pdf (diakses 27 Juli 2018)

Djamarah, S. B. 2002. Strategi Belajar Mengajar. Jakarta: Rineka Cipta. 
Setyandari, A. 2015. Inovasi Pemanfaatan Media Film untuk Peningkatan Kemampuan Listening dalam Pembelajaran Bahasa Inggris. Klaten: Jurnal Magistra Vol 27 No. 91, hal 45-52. Tersedia dalam: http://journal.unwidha.ac.id/index.php/MAGISTRA/article/ view/933/88 (diakses 27 Juli 2018)

Slameto. 2010. Belajar dan Faktor-faktor yang Mempengaruhinya. Jakarta: Rineka Cipta.

Sudjianto. 2012. Metode Pengajaran Menyimak. Direktori File UPI Bandung. Tersedia dalam: http://file.upi.edu/Direktori/FPBS/ JUR.PEND.BAHASA JEPANG/195906051985031SUDJIANTO/11._Makalah_Menyimak.pdf. (diakses 26 Juli 2018)

Sudjiono, A. 2003. Pengantar Statistik Pendidikan. Jakarta: Raja Grafindo Persada.

Tarigan. H.G. 1986. Menyimak sebagai Suatu Keterampilan Berbahasa. Bandung: Angkasa. 